Sylte, A. L. (2018). Profesjonsretting og studentaktivitet. Scandinavian Journal of Vocations in Development http://dx.doi.org/10.7577/sjvd.2694

Fagfellevurdert artikkel

\title{
Profesjonsretting og studentaktivitet
}

Forfatter:

Ann Lisa Sylte

Førstelektor

OsloMet - Storbyuniversitet

Fakultet for lærerutdanning og internasjonale studier, Institutt for yrkesfaglærerutdanning asylte@oslomet.no

\section{Nøkkelord}

Universitets- og høgskolepedagogikk i profesjonsutdanning, relevans, didaktiske prinsipper, koherens, Flipped Classroom. 


\section{Sammendrag}

Resultater fra et aksjonsforskningsprosjekt, gjennomført som utviklingsforsøk ved Universitets- og høgskolepedagogisk basiskurs for lærere i profesjonsutdanninger, viser eksempler på sentrale prinsipper for profesjonsrettet og studentaktiv profesjonsutdanning.

Et problem i mange profesjonsutdanninger er lav studentaktivitet, lav relevans i forhold til aktuelt yrke og mangel på sammenheng i utdanningsinnholdet.

Det ble gjort forsøk med profesjonsretting og studentaktivitet inspirert av Flipped Classroom (omvendt undervisning) for å imøtekomme utfordringene. Kjernen i prinsippene er analyse av yrkesoppgaver og -utøvelse som utgangspunkt for læreplananalyse og profesjonsdidaktisk planlegging av innhold, undervisning og vurdering, knyttet til koherens og helhetlig yrkeskompetanse. Hjemmearbeid og studentaktiv læring gjennom refleksjon i og over praksis er også viktig.

Men resultatene viser også utfordringer med profesjonsretting og behov for utvikling av profesjonsdidaktisk lærerkompetanse. 


\section{Introduksjon}

Universitets- og høgskolepedagogisk basiskompetanse (UHped), som er et grunnleggende praktisk-pedagogisk kurs for undervisere i for eksempel sykepleier-/ ingeniørutdanning, skulle utvikles med vekt på profesjonsperspektivet. Det har lenge vært krav om at nytilsatte undervisere $\mathrm{i}$ universitets- og høgskolesektoren skal ha dokumentert relevant praktiskpedagogisk kompetanse (Forskrift om ansettelse og opprykk, 2006, §1-6). Nå-situasjonen ble kartlagt gjennom intervjuer av tidligere studenter ved UHped og fakultetsledelsen, som viste at profesjonsutdannere trenger å lære praktisk-teoretisk planlegging, gjennomføring og vurdering av læring og undervisning som er relevant for utdanningens yrkesutøvelse og samfunnsmandat. Det binnebærer profesjonsdidaktikk (Sylte, 2016, s. 13): «Praktisk-teoretisk planlegging, gjennomføring, vurdering og kritisk analyse av yrkesspesifikke utdannings- og læringsprosesser i skole og arbeidsliv» (Hiim \& Hippe, 2001, s. 19). Profesjonsutdanninger skiller seg fra andre høyere utdanninger ved at de leder til spesifikke yrker i stedet for en fagdisiplin. Dermed krever profesjonsutdanninger yrkes- og praksisnær utdanning (Billett \& Choy, 2013). Resultater fra eget aksjonsforskningsprosjekt viste hvordan yrkesretting fremmet relevant og praksisnær yrkesutdanning på videregående nivå (Dahlback, Hansen, Haaland \& Sylte, 2011; Hiim 2013, 2014, 2015; Sylte, 2015, 2016). De didaktiske prinsippene for yrkesrettingen som fremmet relevans, innebar at innholdet, arbeidsmåtene og vurderingen var basert på yrkesoppgaven og -utøvelsen. Jeg var engasjert som en to kursansvarlige for å videreutvikle det samlingsbaserte pilotkurset UHped. Der skulle jeg bidra med profesjonsdidaktisk kunnskap. Derfor var det interessant å undersøke om didaktiske prinsipper for yrkesretting kunne være relevant på universitets- og høgskolenivå, for å utvikle relevant profesjonsutdanning. Profesjonsretting har fått stor oppmerksomhet og er vektlagt $\mathrm{i}$ politiske føringer (Forskrift om rammeplan for lektorutdanning, 2013; Meld.St. 16, 20162017; Meld.St. 13, 2011-2012; St.meld. nr. 7, 2007-2008; St.meld. nr. 11, 2008-2009).

Dette var bakgrunnen for et aksjonsforskningsprosjekt hvor min visjon var profesjonsretting av høyere utdanningi. Dette aksjonsforskningsprosjektet var en videreføring av resultatene fra aksjonsforskningen i yrkesutdanningen. Analysen av gapet mellom nå-situasjonen og visjonen viste behov at et realistisk mål om å sette særegent søkelys på profesjon og yrkesutøvelse knyttet til innhold, arbeidsmåter og vurdering ved UHped. Det ble gjennomført en ny emneplan som la mer vekt på profesjonsperspektivet. Det ga rom for å gjennomføre forskningsbaserte utviklingsforsøk i min praksis, der kjernen var profesjonsrettet 
undervisning. Selv om kurset innebar flere arbeidsmåter, avgrenses artikkelen til min forskning og undervisning i utviklingsforsøkene. Planleggings- og gjennomføringsfasene handlet om å legge vekt på didaktiske utfordringer i profesjonsutdanninger med søkelys på relevansproblemer. Det innebar også behov for å relatere utdanningen tydelig til de praktiske yrkesoppgavene i for eksempel ingeniør- og politiutdanninger, som reiser problemstillingen: Hvordan kan profesjonsretting og studentaktivitet gjennomføres i profesjonsutdanning? Erfaringer fra et aksjonsforskningsprosjekt i basiskurset Universitets- og høgskolepedagogikk.

Et hovedanliggende for forskningen var å utvikle didaktisk kunnskap om profesjonsrettet og studentaktiv relevant utdanning på to nivåer: 1) mitt nivå som lærer ved UHped og 2) profesjonsutdanningsnivået hvor studentene (deltakerne) ved UHped underviste. Utfordringen var at pedagogikk- og didaktikkundervisningen på UHped skulle være relevant for deltakernes praksis som lærere. De skulle lære å imøtekomme relevansproblematikken i sine profesjonsutdanninger, gjennom erfaringer med min måte å undervise på.

Først gis en begrepsavklaring før utviklingsforsøkene beskrives kort. Så belyses problemstillingen ut fra tidligere forskning og et pragmatisk kunnskapsteoretisk perspektiv. Videre beskriver jeg aksjonsforskingstilnærmingen. Resultatene av deltakernes erfaringer og opplevelser fra utviklingsforsøkene presenteres og drøftes mot artikkelens teorigrunnlag før konklusjon.

\section{Begrepsavklaring}

Profesjonsretting i lærerutdanning betyr: «(...) kobling mellom teori og praksis og mellom fag, fagdidaktikk, pedagogikk og FoU-prosjekter» (St.meld.11, 2008-2009, s. 53). Relevant lærerutdanning innebærer at studentenes faglige kompetanse knyttes til det å undervise. Begrepet akademisering handler om en vitenskapelig kunnskapsbase som forventes å styrke profesjonskvalifiseringen (Terum \& Smeby, 2014). Det innbefatter at den teoretiske kunnskapsbasen blir styrket. Imidlertid kan det også være at den teoretiske kunnskapen som vektlegges ikke er tilstrekkelig relevant. Profesjonsretting handler om å legge til rette for at utdanningen som helhet er relevant for yrkesutøvelsen. Det vil si at begreper og begrepsstrukturer i utdanning og læring er sentrert rundt analyse av yrkesoppgaver og utøvelsen. Profesjonsretting av utdanningsinnholdet, arbeidsmåter og vurderingsformer kan anses som en forutsetning for relevant profesjonsutdanning (Hiim, 2014; Sylte, 2016). 


\section{Prosjektets praktiske gjennomforing}

Prosjektet var organisert med tre utviklingsforsøk gjennomført i fire runder over et semester hver ved UHped. Deltakerne underviste i ulike profesjonsutdanninger mellom samlingene. Artikkelens hovedfokus rettes til de didaktiske kategoriene innhold, arbeidsmåter og vurdering, selv om kategoriene mål, læreforutsetninger og rammefaktorer sees i en helhetlig relasjonstenkning hvor alle kategoriene er gjensidig avhengig av hverandre med yrkesoppgaven i sentrum (Hiim \& Hippe, 2001; Sylte, 2016).

I første forsøk skulle deltakerne praktiskteoretisk lære profesjonsdidaktisk analyse av yrkesoppgaver. Det skulle danne

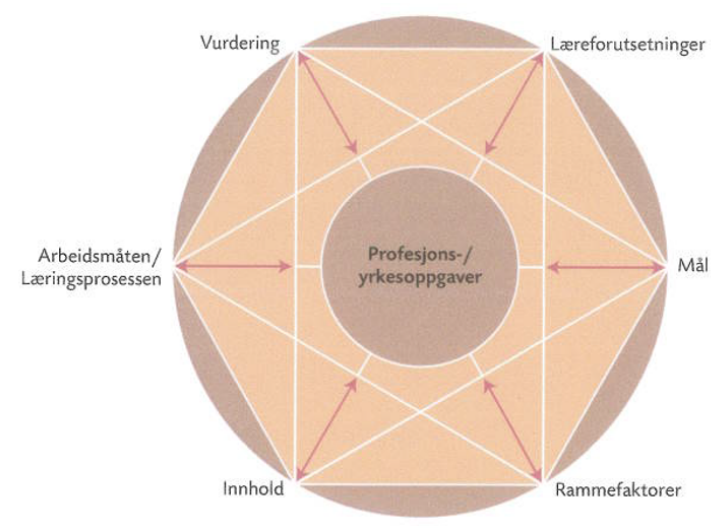

Figur 1: Praktisk-teoretisk didaktisk relasjonsmodell (Sylte, 2016, s. 52, etter Hiim og Hippe, 2001, s. 32) utgangspunkt for egen undervisningsplanlegging gjennom didaktisk relasjonstenkning. I andre forsøk skulle deltakerne praktisk-teoretisk lære å utarbeide vurderingsverktøy med beskrivelse av kjennetegn på kvalitet som lav, middels og høy måloppnåelse (Sylte, 2014). I tillegg skulle de lære om vurdering med kjennetegn knyttet til helhetlig yrkeskompetanse med utgangspunkt $\mathrm{i}$ analyse av yrkesoppgaver og fagplan ${ }^{\mathrm{ii}} \mathrm{i}$ egen profesjonsutdanning. I tredje forsøk skulle deltakerne praktisk-teoretisk lære hvordan profesjonsretting kunne realiseres gjennom studentaktive arbeidsmåter inspirert av Flipped Classroom (FC [FC brukes videre om studentaktivitet inspirert av FC]). FC er en relativt ny didaktisk metode som bruker eksempelvis videoforelesninger eller lesing av teori som forberedelse, og studentaktive problemløsningsaktiviteter i klasserommet (Bergmann \& Sams, 2011). Kjernen i FC er at det studentene kan gjøre individuelt hjemme, frigjør tid i klasserommet til for eksempel profesjonsretting.

\section{Profesjonsretting og studentaktivitet: Tidligere forskning}

Relevansproblematikken har preget profesjonsutdanninger gjennom et skille mellom teori og praksis (Hatlevik, 2014; Hiim, 2010, 2015a; Molander \& Terum, 2010; NOKUT, 2006; Smeby \& Mausethagen, 2011; Statistisk sentralbyrå [SSB], 2014). Forskning viser at nyere profesjonsutdanninger som tidligere var yrkesutdanninger, har blitt mer akademisert ved at opplæringen er mer atskilt fra yrkesutøvelsen (Terum \& Smeby, 2014). De sier også at det er 
spesielt store forventninger om relevans og nytte for arbeidslivet profesjonsutdanninger. Annen forskning peker på behovet for å tydeliggjøre profesjonsutdanningenes yrkesrelevans og styrke forankringen til arbeidslivet for å øke utdanningskvaliteten (Billett, 2014; Hiim, 2013). Forskning viser nødvendigheten av at det teoretiske utdanningsinnholdet tar utgangspunkt i og har sammenheng med yrkesoppgavene og -utøvelsen (Hiim, 2015a; Sylte, 2016). Problemet er at denne sammenhengen ofte mangler i profesjonsutdanninger (Billett, 2010; Hatlevik, 2014; Sullivan \& Benner, 2005).

Kvalitetsreformen for høyere utdanning skulle blant annet øke kvaliteten på utdanningen og fremme studentaktivitet. Evaluering av reformen viser at studentene er mer aktive og får mer skrivetrening. De setter pris på å få tilbakemeldinger, selv om kvaliteten på tilbakemeldingene oppleves noe moderat (Michelsen \& Aamodt, 2007). Til tross for studentaktivitet er mer vektlagt, er imidlertid innholdet i profesjonsutdanninger ofte preget av inndeling i vitenskapsdisipliner og teori som er løsrevet fra praksis og yrkesutøvelsen (Billett, 2014; Hiim, 2010; Sullivan \& Benner, 2005). Innholdet i profesjonsutdanninger må begrunnes først og fremst ut fra relevansen den har for selve yrkesutøvelsen (Smeby, 2008). Typisk for profesjonenes bruk av kunnskap er at det er den praktiske oppgavens karakterer som bestemmer hva slags elementer fra profesjonens kunnskapsbase som bør knyttes sammen. Det vil si praktiske synteser (Grimen, 2008). Mens problemet er at teorien i utdanningen ofte ikke oppleves som og kanskje heller ikke er relevant for det yrket det utdannes til. Teorien er ofte ikke utviklet i tilknytning til det aktuelle yrket og har heller ikke vært gjenstand for en profesjonsrettet praktisk syntese. Imidlertid viser resultater fra aksjonsforskningsprosjektet i yrkesutdanningen at yrkesrettet undervisning hvor innholdet, arbeidsmåtene og vurderingsformen tar utgangspunkt i yrkesoppgaver og elevenes praksiserfaringer, oppleves meningsfylt og relevant, og er kompetansefremmende (Dahlback et al., 2011; Hiim, 2014, 2015; Sylte, 2015).

Hensikten med arbeidsmåten Flipped Classroom (FC) i prosjektet, var å undersøke om FC kunne gi rom for profesjonsretting. Lage, Platt \& Treglia (2000, s. 32) definerer FC som: «Inverting the classroom means that events that have traditionally taken place inside the classroom now take place outside the classroom and vice versa». Forskning viser at karakterene til studentene med FC (web-forelesninger) var signifikant høyere enn kontrollgruppen som hadde tradisjonell undervisning (Day \& Foley, 2006). I mitt prosjekt var hensikten å anvende den frigjorte tiden til å profesjonsrette undervisningen gjennom å 
definere og diskutere utfordringer i deltakernes lærerpraksis og knytte teori sammen med deres erfaringer. Bishop og Verlegers (2013) forskning omhandlet 24 studier av ulike former for samarbeidslæring knyttet til FC. Resultatene viste at studenters oppfatninger av FC var noe blandet, men helhetlig sett generelt positive. Studentene hadde en tendens til å foretrekke forelesninger med lærer fremfor videoforelesninger, mens de foretrakk interaktive klasseromsaktiviteter fremfor forelesninger. Day og Foleys (2006) forskning viste at studenters læring økte med bedre eksamensresultat ved FC versus tradisjonell undervisning.

Forskning på vurderingsformer viser at fokuset er flyttet fra vurdering $a v$ læring, gjennom vurdering for læring, til vurdering som læring (Smith, 2009; Torrance, 2007). Selv om forskning viser at egenvurdering i profesjonsutdanning gir bedre læring, peker den på at utfordringen er om selve yrkesutøvelsens kompetansebehov blir gjenspeilet i vurderingskriteriene (Baartman, Gulikers \& Dijkstra, 2014).

Komparativ lærerutdanningsforskning med data fra 486 lærerstudenter fra fem lærerutdanningsprogram i fem land, peker på koherens (sammenheng) mellom teori og praksis som helt sentralt. De undersøkte om lærerstudentene opplevde sammenheng i lærerutdanningsprogrammet og mellom undervisningen på utdanningsinstitusjonen og pedagogisk praksis. Studentene som var med i et program med spesifikke forsøk på å koble teori og praksis sammen over en periode på 15 år, opplevde økt koherens. Mens studentene fra et program hvor det kontinuerlig ble arbeidet med forbedringer av utdanningen uten spesifikt fokus på koherens, opplevde mindre koherens (Canrinus, Bergem, Klette \& Hammerness, 2015). Oppsummert peker den belyste forskningen på behov for profesjonsretting av innhold, arbeidsmåter og vurderingsformer som innebærer koherens. Derfor ser jeg behov for å imøtekomme relevansproblematikken gjennom profesjonsretting.

\section{Profesjonsretting i et pragmatisk kunnskapsteoretisk perspektiv}

Pragmatisk kunnskapsteori fremhever nødvendigheten av å lære profesjonskunnskap gjennom deltakelse i meningsfylte praksiskontekster. Et pragmatisk perspektiv på læring «(...) innebærer at erfaring og språk blir ansett som en prosess hvor begreper blir utviklet gjennom deltakelse i praktiske kontekster» (Hiim, 2013, s. 313). Pragmatisk kunnskapsteori utgjorde et forståelsesgrunnlag i aksjonsforskningen gjennom profesjonsdidaktisk tenkning (Sylte, 2016). Kontekstuell læring med utgangspunkt i yrkesoppgaven er kjernen her. Det forutsetter 
studentaktiv læring gjennom handling, erfaring, kommunikasjon og refleksjon (Dewey, 1910; Kolb, 1984/2012; Schön, 1983). En viktig forskjell på pragmatisk profesjonspedagogisk og didaktisk relasjonstenkning versus konvensjonell pedagogisk tekning, er at utdanningen med læreplaner, innhold, undervisning og vurdering er basert på selve yrkesoppgaven og utøvelsen, i stedet for kontekstfri abstrakt teori (Hiim \& Hippe, 2001; Sylte, 2016).

Utvikling av helhetlig yrkeskompetanse fordrer at oppgavene er virkelighetsnære, praksisbaserte og åpne. Helhetlig yrkeskompetanse har et ekspertnivå som innebærer å skjelne mellom ulike situasjoner som krever praktisk-teoretisk kunnskap og ulike handlinger (Dreyfus \& Dreyfus, 1986). I motsetning til konvensjonell læringsforståelse som er mer basert på rasjonalistisk erkjennelsesteori, har den erfaringsbaserte læringsprosessen et fundamentalt annerledes syn på læring (Kolb, 1984/2012). Det har vært en allmenn antakelse at teori er en viktig forutsetning for profesjonell praksis. Teori er viktig, men både læring og teoriutvikling kan skje gjennom refleksjon i og over praksis (Hiim, 2015; Schön,1995). I prosjektet var det et hovedanliggende at deltakerne skulle erfare og lære gjennom ulike eksempler på undervisningsmetoder som innebar didaktiske prinsipper for profesjonsretting. Deltakerne skulle være aktivt deltakende i egen læringsprosess og læringen skulle skje i dialog med praksis (Dewey, 1910). Målet var at den didaktiske kunnskapen ble varig, også etter prosjektets slutt i tråd med Reason og Bradburys (2008) validitetskriterier for aksjonsforskning. 


\section{Prosjektets forskningstilnærming}

Forskningstilnærmingen i prosjektet var aksjonsforskning. Den har utgangspunkt i hermeneutisk-fenomenologisk vitenskapelig retning. Det kjennetegnes ved sitt empiriske utgangspunkt versus konvensjonell deduktiv forskning fra den naturvitenskapelige positivistiske retningen (Amble, 2012). I aksjonsforskning er felles læringsprosess mellom felt og forsker mer vektlagt, hvor ny kunnskap skal være relevant i feltet og ha vitenskapelig standard (Svensson \& Nielsen, 2006). Aksjonsforskning kan ha ulike vitenskapsteoretiske tilnærminger. Prosjektet var mest inspirert av pedagogisk aksjonsforskning inspirert av pragmatisk didaktisk relasjonstenkning hvor jeg forsket i egen praksis som lærer i interaksjon med deltakerne (Hiim, 2010). Den indre sammenhengen i aksjonsforskningsforsøkene, var de didaktiske kategoriene innhold, arbeidsmåter og vurdering som er relatert til hverandre gjennom en helhetlig didaktisk planlegging, gjennomføring og vurdering av lærings- og undervisningssekvenser (Hiim \& Hippe, 2001).

\section{Hovedtrekkene i studien - deltakerne, utviklingsforsøkene og empirigrunnlaget}

Det ble brukt ulike metoder i datainnsamlingen, men alle hadde samme fokus på profesjonsretting og FC. Som tidligere beskrevet, innebar utviklingsaktivitetene som genererte data tre utviklingsforsøk utprøvd i fire semestre/ runder med totalt 20 pedagogiske verkstedssamlinger, samt veiledning mellom samlingene. Deltakerne var 62 studenter som underviste i ulike profesjonsutdanninger som f.eks. politi-, sykepleier- og ingeniørutdanning mellom samlingene. Deltakerne hadde ulik kompetanse og erfaringer, fra høgskolelærer til professor. Noen hadde undervist i flere år, mens andre var nytilsatte.

Jeg skrev logg fra min deltakende observasjon av utviklingsforsøkene. Loggene (12) innebar referat fra samlingene, deltakerutsagn og sitater fra interaksjonen med og mellom deltakerne. Jeg intervjuet to deltakere ved hjelp av halvstrukturert intervjuguide og gjorde også en kvalitativ spørreunderundersøkelse blant deres 40 studenter. 30 deltakere samtykket til å vise eksempler fra deres oppgaver hvor fem konkrete empiriske eksempler er inkludert i artikkelen. Eksemplene innebar deltakernes beskrivelser og refleksjoner over egne utviklingsforsøk i deres profesjonsutdanninger. Evaluering (16) av deltakernes erfaring og nytteverdi av forsøkene, dannet grunnlag for utviklingen i prosjektet. De kvalitative utsagnene fra evalueringen er med i datagrunnlaget. 


\section{Utviklingsprosessen i aksjonsforskningen}

De konkrete endringsfasene ble strukturert etter en prosessmodell for utviklingsprosjekt (Figur 1). Nå-situasjonen, visjonen og målet for aksjonsforskningen er belyst i introduksjonen.

Planleggings- og

gjennomføringsfasene foregikk i fire runder (illustrert som 1,2,3 i modellen) over et semester hver.

Eksempelvis startet semestret med utgangspunkt i deltakernes beskrivelse av en erfart utfordrende undervisningssituasjon som grunnlag for diskusjon og refleksjon for å utvikle visjoner og nye løsninger.

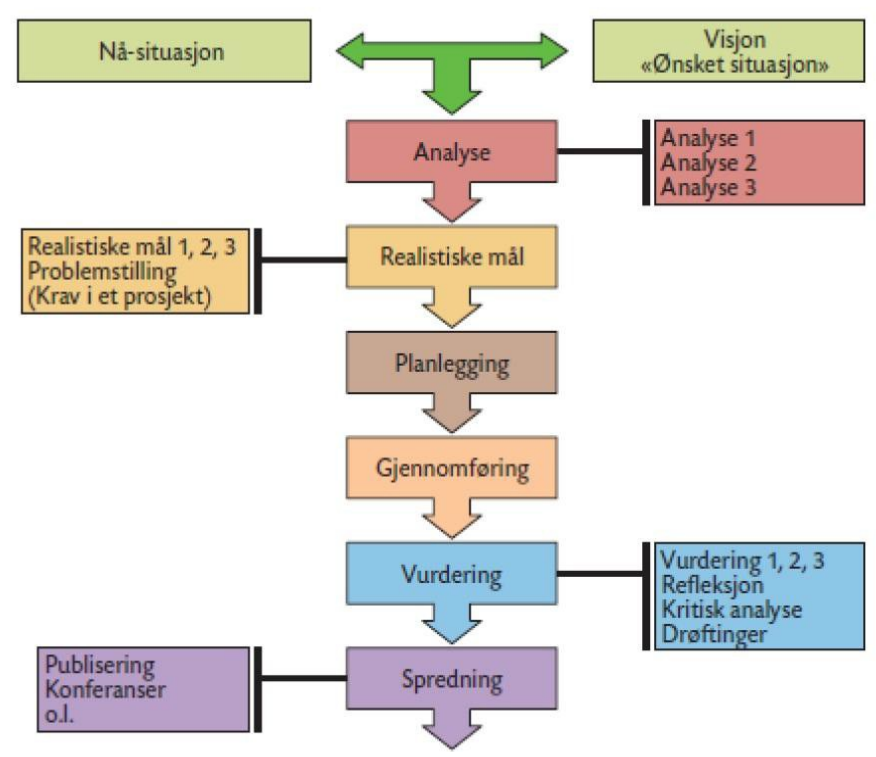

Figur 2: Prosessmodell i et utviklingsarbeid/-prosjekt (Sylte, 2016, s. 237)

Innholdet på samlingene dreide seg om praktisk-teoretisk kunnskap om prosesjonsrettet og studentaktiv utdanning. For å ivareta Reason og Bradburys (2008) validitetskriterier for aksjonsforskning om at kunnskapsutviklingen oppleves nyttig og relevant for deltakernes praksis, ble innholdet og arbeidsmåtene kontinuerlig justert underveis fra samling til samling, ut fra deltakernes uttrykte behov innenfor rammen for UHped. Undervisning med praktiske øvelser, FC og interaksjon med refleksjon hvor deltakerne knyttet teori og praksis sammen, var de viktigste arbeidsmåtene på samlingene. Det ble bygd strukturer der både deltakerne og jeg gjorde endringer i egen praksis, reflekterte over erfaringene på samlingene, gjorde nye endringer og lærte av erfaringene for å forbedre prosessene slik en selv ønsket. Dette var en viktig del av profesjonsrettingen og utviklingen i prosjektet.

Vurderingsfasen innebar at deltakerne kontinuerlig evaluerte forsøkene, både skriftlig og i gruppediskusjoner, med mål om videreutvikling av prosjektet. Denne interaksjonen ga meg viktige innspill i utformingen av neste samling med nye forsøk. Både deltakerne og jeg erfarte at den kollektive kritiske refleksjonen rundt det deltakerne erfarte, førte til tanker som ble konstruert om til nye handlinger i en sirkulær prosess gjennom flere aksjoner (Schön, 1983). Deltakerne uttrykte at medvirkningen, dialogen og erfaringsutvekslingen på tvers av profesjonsutdanninger var svært utviklende i tråd med Schwenckes (2006) forskning om 
dialogens betydning i aksjonsforskning. Interaksjonen kunne for eksempel innebære deltakernes kritiske refleksjon over undervisningsøvelser knyttet til pedagogisk og didaktisk teori, i dialog med meg og deltakerne. Deltakerne fremhevet dialogen, erfaringsutvekslingen og de demokratiske prosessene, som gjorde at samlingene opplevdes som et slags «frirom». Nielsen (1996, s. 359) lanserte friromsbegrepet som et alternativt begrep til de dialogpregede metodene i aksjonsforskning. Deltakerne kom med flere utsagn som: «Svært engasjerte deltakere, som har kommet med mange interessante innspill og deltatt aktivt i diskusjoner. Dette har tilført meg mye». De største utfordringene i prosjektet var at deltakerne opplevde vanskelige rammer for profesjonsretting i egen utdanning. Mine utfordringer handlet om rammen for aksjonsforskningen fordi jeg gjennomførte den i egen praksis som medansvarlig for et pilotprosjekt hvor det kun var jeg som forsket på utviklingsprosessene.

\section{Analyse, gyldighet og relevans - validitet}

Hovedprinsippet var at alle ut fra sitt mandat dokumenterte sin praksis på first-, second- og third-person-nivå (Reason \& Bradbury, 2008). Jeg forsket i min praksis og til dels i deltakernes. Det var nødvendigvis sammenheng og overlapping mellom de ulike nivåene på en måte som ble klargjort i hvert enkelt forsøk. En viktig oppgave var å sammenlikne flere ulike deltakeres dokumentasjon fra sin praksis på third-person-nivået. Analysearbeidet besto av systematisk, kritisk analyse og sammenfatning av deltakeroppgaver, logger, intervju, spørreundersøkelser og evalueringer. Empirien ble analysert og syntetisert underveis for utvikling av forsøkene, og for å se sammenhenger og mønstre. Jeg tolket disse i tråd med hermeneutisk fortolkningsmetode hvor jeg ikke var ute etter en objektiv sannhet eller målbare resultater. Jeg pendlet mellom ulike perspektiver som helhet og del ut fra min førforståelse og prosjektets teoretiske ramme (Gadamer, 2010).

En vanlig kritikk mot aksjonsforskning er at det gis stort spillerom for forskerens dømmekraft og vurderingsevne (Grimen, 2004). Siden jeg forsket i egen praksis med utvikling av UHped, var jeg bevisst på forskerrollen fordi den også innebar lærerrollen. Det kunne være at deltakerne ikke våget å si hva de mente. For å unngå å være suveren i forskerrollen $\mathrm{i}$ utvelgelsen av empiriske eksempler, og måten forskningstilnærmingen ble gjennomført på, stilte jeg kritiske spørsmål knyttet til validitet, som eksempel: Hvordan kan det deltakerne egentlig sa, gjengis og ikke det jeg ønsket de skulle si (Eikeland, 2006)? Deltakerne fikk korrekturlese transkripsjonen av intervjuene som først ble tatt opp på diktafon, for å sikre og 
korrigere min tolkning. Jeg drøftet kontinuerlig og reflekterte kritisk med deltakerne om deres erfaringer og opplevelser av utviklingsforsøkene (Reason \& Bradbury, 2008).

Jeg transkriberte og sammenfattet dataene ut fra selvforståelse, kritisk forståelse basert på sunn fornuft og analysenivået med teoretisk forståelse (Kvale \& Brinkmann, 2009). Analysen og kategoriseringen var dels inspirert av grounded theory (Strauss \& Corbin, 1997) og tok dels utgangspunkt i teoretiske begreper. Basert på pragmatisk teoretisk didaktisk relasjonstenkning, analyserte jeg deltakernes opplevelse av relevans knyttet til kategoriene profesjonsretting av innhold, arbeidsmåter og vurdering. Underkategorier som fremkom var muligheter og utfordringer som jeg i analysen knyttet til deltakernes og deres studenters erfaringer med profesjonsretting. Det var viktig å artikulere kategoriene for å produsere didaktisk kunnskap som fremstod som original og valid slik at andre kunne lære av det (Hiim, 2010; McNiff \& Whitehead, 2006).

\section{Presentasjon av resultater}

Resultatene fra forsøkene presenteres kronologisk knyttet til analysekategoriene.

\section{Første utviklingsforsøk}

Øvelsen med fokus på yrkesoppgaver, analyse av kvalifikasjonsbehov og læreplananalyse i egen profesjonsutdanning, opplevdes, ifølge deltakerne, som svært nyttig og relevant. Likedan opplevde de den praktisk-teoretiske undervisningsplanleggingen gjennom den didaktiske relasjonsmodellen i egen utdanning, som nyttig og meningsfull. Refleksjonen og drøftingen underveis mente de var relevant og nyttig.

Didaktisk undervisningsplanlegging basert på yrkesoppgavene var nytt for alle, selv de med lang undervisningserfaring. Deltakerne sa blant annet: «Blitt mer bevisst på å planlegge undervisningen knyttet til mål og yrkesoppgaven». «(..) svaert bevisstgjørende og utviklende». «Veldig fornøyd med «åpne oppgaver» slik at jeg kan vinkle de mot min undervisningspraksis».

Evalueringen viste at det også var deltakere som var mindre opptatt av profesjonsretting i starten av UHped-kurset. Noen var mer opptatt av egen fagdisiplin. Noen ønsket mer vekt på forskningsbaserte artikler med teori som angir prosedyrer for anvendelse av læreryrket: «Bruke publikasjoner i Science som «bevis»for ufeilbarlighet». 
Noen eksempler på deltakernes forsøk med profesjonsretting med yrkesoppgaven som utgangspunkt for undervisningen er følgende:

- Sykepleierstudenter fikk teori om hygiene relatert til praktiske øvelser med sprøytestikking på dukker.

- Politistudenter fikk teori fra f.eks. jus, psykologi og sosiologi relatert til øvelser med planlegging og gjennomføring av politiavhør.

Deltakere erfarte at deres forsøk opplevdes nyttige og relevante av deres studenter. Samtidig ønsket flere deltakere pedagogisk oppfølging med vekt på profesjonsretting av undervisningen etter kursets slutt. Begrunnelsen var behov for kontinuerlig utvikling av didaktisk lærerkompetanse om profesjonsretting.

Resultatene peker mot at både deltakerne og deres studenter opplever profesjonsretting som relevant og nyttig, men at det ifølge deltakerne er liten tradisjon og kultur for profesjonsretting i profesjonsutdanningene.

\section{Andre utviklingsforsøk}

Deltakerne øvde på analyse av læringsutbyttebeskrivelser i egen profesjonsutdanning og utarbeiding av kjennetegn. Kjennetegnene beskrev lav, middels og høy måloppnåelse knyttet til helhetlig yrkeskompetanse. Det innebar at deltakerne laget kjennetegn på eksempelvis begrunnelse og utøvelse av hygiene ved bruk av sprøyter. Deltakerne opplevde dette som nyttig og relevant. Kjennetegnene var basert på yrkesoppgavene og innebar i tillegg nøkkelkompetanse som f.eks. samarbeid, ansvarlighet og nøyaktighet knyttet til den praktiskteoretiske yrkesoppgaven som en helhetlig yrkeskompetanse. Mange deltakere opplevde at vurdering med kjennetegn kunne være et nyttig verktøy for å bevisstgjøre studentene på hva som skal til for å få øke kvaliteten i profesjonskvalifiseringen. Deltakerne opplevde å bli mer bevisste på hvordan de kunne løse utfordringer med vurdering gjennom vurderingsøvelsen. De sa blant annet: «Dette ga tips og konkrete eksempler på utfordringer og hvordan disse kan løses». «Super nyttig - kan se anvendelse i mitt kurs». Derimot opplevde flere deltakere utfordringer med analyse av fagplanen: «Det er vanskelig å vurdere helhetlig yrkeskompetanse når fagplanen etterspør mest teoretisk kunnskap».

Mange deltakere uttrykte utfordringer i sine utdanninger med vurderingsformer som kun etterspør teoretisk kunnskap i stedet for helhetlig yrkeskompetanse. Et eksempel fra en deltaker som erfarte etiske utfordringer i egen vurderingspraksis er følgende: 
- En sykepleiestudent fikk B, selv om ett av eksamenssvarene var så feil at det $\mathrm{i}$ virkeligheten ville ha tatt livet av pasienten. Eksamenen bestod av mange teorispørsmål som ble poenggitt og summert. Samlet sett ga $\mathrm{x}$ antall poeng gitte karakterer. Imidlertid var et av spørsmålene slik at hvis studenten svarte feil, så ville konsekvensen i praksis være svært alvorlig. Studenten svarte helt korrekt på de øvrige spørsmålene. Dermed kunne ikke deltakeren gi dårligere karakter enn B, på tross av feil svar på et så livsviktig spørsmål. Dette var en vanlig eksamensform ved utdanningen.

«Får studentene vist sin helhetlige yrkeskompetanse eller etterspør vi mest fragmentert teoretisk kunnskap som studentene må pugge seg frem til og ikke forstår konsekvensene av $i$ praksis?», undret deltakeren seg. Flere deltakere sa de ble inspirert til å arbeide med vurdering med kjennetegn i egne profesjonsutdanninger. Men ingen gjorde egne forsøk med slik profesjonsrettet vurdering. Flere opplevde at vurderingsformen i profesjonsutdanningene ikke ga rom for å vurdere helhetlig yrkeskompetanse.

Resultatene indikerer at deltakerne opplever profesjonsrettet vurdering med vekt på helhetlig yrkeskompetanse som nyttig og relevant, men at det ifølge deltakerne er utfordringer i fagplanene, og at vurderingsformen er låst i strukturelle rammer. I tillegg mente deltakerne at det ikke er tradisjon og kultur for profesjonsrettet vurdering i profesjonsutdanningene.

\section{Tredje utviklingsforsøk}

Forsøkene innebar to sekvenser med profesjonsretting gjennom FC. Deltakerne gjorde hjemmeforberedelser med en video om praktisk-teoretisk veiledningsmetodikk og beskrev en erfart utfordrende undervisningssituasjon. Praktiske verktøy for å håndtere lav studentaktivitet og profesjonsretting, var uttrykte undervisningsutfordringer blant deltakerne: «Hvordan kan jeg praksisrette undervisningen?» «Hvordan få studentene til å forberede seg?». Mange uttrykte at de følte mer ansvar og forpliktelse til å være forberedt av hensyn til meddeltakere. Forberedelsene dannet grunnlaget for veiledningsøvelse av hverandre på samlingen. Teori om veiledning ble anvendt i øvelsen. I tillegg reflekterte og drøftet deltakerne sine undervisningsutfordringer knyttet til utøvelse av skjønn, danning og samfunnsmandatet som lærer i profesjonsutdanninger.

Om sekvensen med veiledning på profesjonsretting sa deltakerne følgende: «Jeg opplever at den økte aktiviteten ved praktiske øvelser med veiledning gir meg en større innloering enn den 
tradisjonelle forelesningsmetoden». «Veiledningsøvelsen (...) var nyttig», «(...) veldig fornøyd». De fleste og særlig de med lang undervisningserfaring opplevde at veiledning på erfarte undervisningsproblemer gir større trygghet i lærerrollen: «Fått mer tillit til å bruke studentdeltakelse/studentaktive undervisningsmetoder». Noen mente at mangel på didaktisk kompetanse kunne være den største utfordringen for både profesjonsretting og bruk av FC: «Relevant at kurset er rettet mot «hvordan undervise» - ønsker mer av det», «(...) den største hindringen mot å snu undervisningen ligger hos loererne».

Den andre sekvensen innebar forberedelse med lesing av pensumartikler (pedagogisk teori) og artikkelpresentasjoner på samlingen. Selv om noen opplevde at forberedelsene ga stor arbeidsmengde, opplevde de likevel mer læring. En deltaker sa: «(...) å legge frem artikler har gitt mest laering». Deltakerne ga tilbakemelding og formativ vurdering på hverandres presentasjoner: «Vi loerer og fär tilbakemelding $i$ en reell kontekst». I tillegg var det gruppeog plenumsdiskusjoner om hvordan teorien kunne utvikle deltakernes undervisningspraksis. Flere opplevde sekvensen relevant og nyttig. Mange deltakere etterlyste imidlertid større relevans i pensumlitteraturen og sa blant annet: «Ønsker mer praktiske bøker», «Ønsker mer om konkrete praktiske undervisningsmetoder, få råd, tips, og tilbakemelding».

Tilbakemeldingene og refleksjonen førte til at jeg i andre runde også etablerte kollegaveiledning i deltakernes undervisningspraksis. Der veiledet deltakerne hverandre i grupper mens de underviste i egen profesjon. De planla undervisningsøkten gjennom et veiledningsdokument strukturert etter didaktisk relasjonstenkning. Rollene i gruppen rullerte slik at alle fikk erfaring med undervisning, veiledning, observasjon og tilbakemelding. I neste runde veiledet også jeg minimum en gang i hver gruppe, noe alle fremhevet som svært lærerikt.

Alle deltakerne mente at $\mathrm{FC}$ bør kun brukes som variasjon blant flere arbeidsmåter. Flere så også behov for tradisjonelle forelesninger med vekt på teoretisk kunnskap.

Noen eksempler på deltakernes forsøk med profesjonsretting og $\mathrm{FC} \mathrm{er} \mathrm{følgende:}$

- Sykepleiestudenter fikk animasjon (web-forelesning) om hjerneslag som hjemmeforberedelse til klasserommet og repetisjon. Animasjonen innebar tegning og forklaring om de viktigste årsaksmekanismene ved hjerneslag. Animasjonen hadde et preg av tavleundervisning, men i digitalt format. På slutten av animasjonen var det lagt inn en caseoppgave som utgangspunkt for dialog og refleksjon om praksis rundt 
hjerneslag i klasserommet.

- Veterinærstudenter fikk hjemmeforberedelser med beskrivelser av kliniske kasus (yrkesoppgave) og videofilmer. Etter at studentene arbeidet med kasusene i grupper ble disse diskutert i plenum med veterinærutdanneren. I tillegg ble det ble undervist $\mathrm{i}$ læringsverkstedet ved hjelp av anestesiutstyr, videofilmer og hundedukker hvor studentene fikk forskjellige problemstillinger de skulle løse.

- Ingeniørstudenter løste praktiske IT-programmeringsproblemer (yrkesoppgaver). Hjemmeforberedelsene kunne være video-snutter med tekniske modeller med teoretiske forklaringer, litteratur/ oppgaver/ case/ problemstilling. I klasserommet var det felles drøfting og løsning av «problemene» gjennom plenums- og gruppediskusjoner, samt hverandre-vurdering hvor studentene vurderte hverandres arbeidskrav med umiddelbare tilbakemeldinger.

Jeg gjennomførte som nevnt intervjuer av deltakere og en spørreundersøkelse blant deltakernes studenter. Deltakerne svarte at deres studenter lærte gjennom teori rettet til praktisk erfaring basert på yrkesoppgaven. Refleksjon over teori knyttet til arbeidsoppgaven i dialog med medstudenter og lærer, ga også stort læringsutbytte. Profesjonsrettingen ble fremhevet av deltakerne som viktig for studentenes opplevelse av relevans. Deltakerne svarte at strykprosenten gikk ned og studentenes karakterer ble bedre med profesjonsretting og FC: «Høy strykprosent var årsaken til at vi begynte med denne metoden og den har gått ned», «Gjennomsnittskarakteren har økt fra 3,6 til 4,52», «Helt klart at disse studentaktive metodene hvor de heller løser utfordringer og problemer (...) i stedet at vi som laerere har en ren forelesning om temaet, har ført til mye større engasjement, motivasjon og bedre resultat». «Hverandre-vurdering på praktiske yrkesoppgaver hjelper studentene til å gjøre det bedre på neste oppgave og eksamen», sa en deltaker. Det hjalp studentene til å se sammenheng mellom fagene/emnene. Når tilbakemeldingen gis raskt, «(...) virker den og studentene bruker den til å se sammenheng til neste emne i motsetning til når laererne gir en tilbakemelding etter noen uker. Da ser de nesten ikke på tilbakemeldingen og den brukes ikke videre», sa deltakeren.

Deltakerne erfarte at FC friga tid i klasserommet til bedre kontakt med studentene og bedre tilpassing av undervisningen til læreforutsetninger og yrkesoppgaver: «Dette ville vi ikke ha fanget opp i en plenumsforelesning». Derimot så deltakerne store utfordringer med for mye web-undervisning: «Web-undervisning blir ofte for monoton til at studenter orker å se». 
Studentene i spørreundersøkelsen fremhevet at FC friga tid til å jobbe med praktiske oppgaver i klasserommet. Flere studenter opplevde at undervisningen ble mer virkelighetsnær og at de lærte mer: «(...) lcererikt å løse/regne oppgaver/bruke dataprogrammer som likner mer på noe man ville gjort $i$ arbeidslivet istedenfor bare å høre på en foreleser hele tiden», «Bra ̊̊ diskutere teori i praksis, $i$ stedet for forelesning», «Man får tenke etter på ett annat sett. Ser en bild hur det er $i$ arbetslivet».

Flere studenter sa de følte mer ansvar for å forberede seg: «Det var ubehagelig å vare uforberedt til denne undervisningen og det kommer ikke jeg til å vare flere ganger». Studentene mente at FC egner seg til forberedelse, repetisjon og som variasjon: «Ulike undervisningsmetoder og variasjon er viktig».

\section{Realisering av profesjonsretting og studentaktivitet}

Diskusjonen retter søkelyset mot hvordan profesjonsretting av de didaktiske kategoriene innhold, arbeidsmåter som FC og vurdering kan realiseres gjennom helhetlig relasjonstenkning. De øvrige kategoriene mål, læreforutsetninger og rammer blir kun implisitt belyst $\mathrm{i}$ denne helhetlige relasjonstenkningen preget av koherens som helhet og sammenheng $\mathrm{i}$ profesjonsutdanninger. Utfordringer med profesjonsretting og hvilke didaktiske prinsipper som utpeker seg for opplevelse av relevans, vil også betraktes.

\section{Profesjonsretting av innhold}

Ut fra et pragmatisk perspektiv på kunnskap er analyse av yrkesoppgaver og kvalifikasjonsbehov viktig for valg og strukturering av innhold i profesjonsutdanning (Dewey, 1910; Hiim \& Hippe, 2001; Schön, 1983). Resultatene fra utviklingsforsøkene viser at når teorien relateres til konkrete yrkesoppgaver opplevdes den relevant for både deltakerne og deres studenter. Deltakerne og studentene var samstemte om viktigheten av at teori fra flere fag i utdanningen blir sett i sammenheng med yrkesoppgaver og yrkesutøvelsen. Det kan sees i sammenheng med Canrinus et al. (2015) sin forskning om viktigheten av koherens i utdanningen. Når fagfeltene blir benyttet i en praktisk oppgave kan det oppstå det Grimen (2008) kaller praktisk syntese. Et av eksemplene var politiavhør som krever kunnskap om både etikk, jus, psykologi og praktisk øvelse. 
Deltakerne var delte om relevansen teoriinnholdet ved UHped hadde. Mange deltakere opplevde deler av pensumlitteraturen som abstrakt og lite relevant: «Ønsker mer praktiske bøker». De opplevde derimot at forskningsbasert didaktisk kunnskap om profesjonsretting som var utviklet på praksis, var relevant. Andre var imidlertid noe skeptiske til forskningsbasert teori utviklet på praksis, spesielt i starten av UHped. Da var de mer opptatt av teori som angir prosedyrer for utøvelse av læreryrket. Selv om både deltakere og studenter her opplevde relevans med profesjonsrettet teori, synes det å være stor kultur for et disiplinbasert akademisk kunnskapssyn i profesjonsutdanningene (Terum \& Smeby, 2010). Kanskje kan deler av innholdet ved både UHped og deltakernes profesjonsutdanninger bære preg av disiplinbasert teori. Det gjør det vanskelig for studentene å anvende teorien i en profesjonsrettet praktisk syntese. Eksempelvis underviser psykologen i psykologi og juristen i jus, uten at yrkesoppgaven til politi- eller sykepleierstudenten vektlegges. Slike eksempel opplevde deltakernes studenter som lite relevant. En del undervisere synes ofte å være mer opptatt av egen fagdisiplin som eksempel jus eller matematikk, i stedet for å være lærer i en profesjonsutdanning når de starter på UHped-kurset. Det kan diskuteres om dette handler om manglende didaktisk kompetanse for profesjonsretting eller manglende kultur og tradisjon for det. Samtidig viser resultatene at de fleste deltakerne var både interessert i og veldig fornøyde med profesjonsretting. Derimot opplevde de vanskeligheter med å gjennomføre det. Resultatene peker delvis mot hindringer i fagplaner og liten og til dels manglende kultur og tradisjon for profesjonsretting i tråd med tidligere forskning (Terum \& Smeby, 2014).

Dreyfus og Dreyfus (1986) sin teori om ekspertkompetanse innebærer at en yrkesutøver er en som ikke bare utfører tekniske deler av en arbeidsoppgave, men forstår hele yrkesoppgaven inkludert samfunnsoppgaven yrket har. Forståelsen av samfunnsmandatet til yrkesutøveren er også en viktig del av den helhetlige yrkeskompetansen til eksempelvis en politi eller en sykepleier. Å forstå samfunnsmandatet innebærer at utøveren også må lære om seg selv for å takle etiske dilemmaer og utvikle yrkesstolthet - det handler om yrkesdanning. Resultatene viser at både deltakere og studentene opplever relevans når teorien blir anvendt til praktiske problemløsninger som også omhandlet personlige forutsetninger og etiske spørsmål knyttet til helhetlige yrkesoppgaver. Heggen og Smeby (2012) drøfter om læring og utvikling av eksempelvis danning må ha koherens til yrkesutøvelsen: «Ein kan ikkje ha som utgangspunkt at studentane til ei kvar tid skal forstå relevansen av all kunnskapen dei må lære» (s. 11). Det var også noen deltakere som stilte spørsmål ved om all teori må profesjonsrettes. Det kan være at studenter blir så vant til at læreren profesjonsretter at de selv ikke oppøver evnen til å 
se teorien koherent til yrkesutøvelsen. Samtidig viser resultatene fra veiledningsøvelsen større opplevelse av relevans når teorien om danning for utøvelse av skjønn har koherens til yrkets samfunnsmandat i tråd med Canrinus et al. (2015) sin forskning om koherens. Heggen og Smeby poengterer imidlertid også at det må være koherens mellom teori og yrkesutøvelsen.

Det kan spørres om profesjonsretting kan misforstås. Faren er hvis profesjonsretting blir oppfattet som at utdanningens innhold primært skal være på arbeidslivets premisser. Det kan føre til et ensidig instrumentelt fokus på å lære enkle arbeidsoppgaver, inntjening og effektivitet - versus å lære hele arbeidsoppgaven. Ensidig vekt på arbeidslivets premisser fører til teorifattige utdanninger og lite utvikling (Young, 2004).

\section{Profesjonsretting av arbeidsmåter}

Læringen skjedde gjennom hjemmearbeid og deltakeraktivitet på samlingene med refleksjon i og over praksis. Læringen ble således erfaringsbasert og kontekstuell. Dermed ble ikke deltakerne og studentene passive mottakere av teorien, men bidro selv gjennom problemløsing, dialog, handling og refleksjon over praksis (Dewey, 1910; Schön,1983). «Fått mer tillit til å bruke studentdeltakelse /studentaktive undervisningsmetoder», sa en deltaker, mens andre sa de ble mer bevisste på hvordan de praktisk-teoretisk planlegger, gjennomfører og vurderer undervisning med utgangspunkt i yrkesoppgavene (Hiim, 2013). Særlig deltakerne med lang undervisningserfaring opplevde større trygghet i lærerrollen. Det kan indikere at utvikling av ekspertkompetanse krever variert og lang praktisk erfaring (Dreyfus \& Dreyfus, 1986).

Selv om det har vært en allmenn antakelse at teori er en viktig forutsetning for profesjonell praksis, var de fleste deltakerne og alle studentene samstemte om at de lærte av kritisk refleksjon i og over praksis (Schön, 1995). Likevel var det flere deltakere som opplevde hindringer for profesjonsretting i egen profesjonsutdanning. Det kan peke mot behov for at utdanningene lærer studenter å reflektere kritisk over bruk av teorier i praktisk handling. Selv om noen så behov for tradisjonelle forelesninger, opplevde både deltakerne og studentene at profesjonsretting gjennom økt aktivitet og virkelighetsnære praktiske oppgaver med refleksjon, ga mer læring. Slik fikk de trening i å se teorien koherent til yrkesutøvelsen gjennom helhetlig didaktisk relasjonstenkning (Hiim \& Hippe, 2001). Eksempelvis lærte ingeniørstudentene teori om programmering gjennom web-video hjemme. På høgskolen 
reflekterte de over gjennomføringen av dataprogrammeringen i samarbeid med medstudenter: «Ser en bild hur det er $i$ arbetslivet». Deltakere erfarte at karakterene til deres studenter gikk opp og strykprosenten ned i forsøkene med profesjonsretting og FC. Samtidig viste funnene at FC burde kombineres med andre undervisningsmetoder og som variasjon, i samsvar med Bishop og Verleger (2013) og Day og Foley (2006). Et konvensjonelt syn på læring vektlegger mer abstrakt kontekstfri teori der læreren ofte er den mest aktive. Derimot peker funnene her på at FC gir rom for at studenter tar mer ansvar og er mer aktive når innholdet, undervisningen og vurderingen profesjonsrettes.

FC er et verdifullt tilskudd som fremmer tid til profesjonsretting, men FC som metode alene fremmer ikke relevans. Profesjonsrettet utdanning kan imidlertid godt skapes uansett om studentene hører forelesningen før de kommer i klasserommet eller ei. Det avhenger av om lærerne er i stand til å relatere utdanningen til studenters yrkesoppgaver og -utøvelse. Samtidig uttrykte både deltakere og studenter at det også er behov for tradisjonelle forelesninger. Profesjonsdidaktikken kan imidlertid ikke bli en oppskrift på hvordan man profesjonsretter utdanningen, men heller være didaktiske prinsipper som er sentrale for relevant profesjonsutdanning.

\section{Profesjonsretting av vurdering}

Hvis profesjonsutdanningene skal bestrebe seg på å utvikle begynnende ekspertkompetanse, må teorien knyttes tett til refleksjon og intuitiv praktisk handling (Dreyfus \& Dreyfus, 1986). Begynnende ekspertkompetanse innebærer at studenter har variert praksis slik at de begynner å skjelne mellom ulike situasjoner som krever praktisk-teoretisk kunnskap og ulike handlinger knyttet til yrkesoppgaver. På det kompetansenivået er også nøkkelkompetanse som eksempel samarbeidsevne og ansvarlighet, internalisert som en helhetlig yrkeskompetanse. De fleste deltakerne opplevde at vurdering med kjennetegn på måloppnåelse som er strukturert rundt sentrale yrkesoppgaver, var nyttig og relevant i forsøket ved UHped. Problemet flere deltakere erfarte, var derimot at det ofte kan være utfordrende å vurdere helhetlig yrkeskompetanse. Noen opplevde at fagplanen var en utfordring, mens andre erfarte at det ikke var kultur for en slik vurderingsform, og at formen var fastlåst i utdanningsstrukturen. Noen, særlig i starten av UHped-kurset, så heller ikke behov for profesjonsrettet vurdering og var mer opptatt av å måle teoretisk kunnskap i egen fagdisiplin. Hvis man etterspør mest teoretisk kunnskap løsrevet fra praksis, kan det føre til eksempelet med sykepleierstudenten som fikk høy karakter på tross av realisering av den samme handling i praksis. Hvis denne 
vurderingen hadde hatt kjennetegn på kvaliteten av helhetlig yrkeskompetanse, så ville sannsynligvis studenten fått lav måloppnåelse. Det kan også være at studenten ville ha lært konsekvensene av spørsmålet gjennom egenvurdering knyttet til kjennetegnene. Derfor er det viktig som tidligere forskning viser, at selve yrkesutøvelsens kompetansebehov blir gjenspeilet i vurderingskriteriene (Baartman et al., 2014).

Det kan synes som studenters hverandre-vurdering (medstudentvurdering) gir større verdi enn lærerens tilbakemeldinger. Korrigerende umiddelbar feedback på oppgaver er et av de mest betydningsfulle verktøy som influerer på læring (Hattie \& Timberley, 2007). Det kan være at studentene «skjerper» seg mer når de ble vurdert av medstudenter. Her blir ikke studentene bare en i mengden som læreren vurderer. I forsøket ble hverandre-vurderingen gitt umiddelbart mens studentene fordypet seg i oppgaven. Evalueringen av Kvalitetsreformen viste at studenters opplevelse av tilbakemeldinger fra læreren hadde moderat kvalitet (Michelsen \& Aamodt, 2007), mens hverandre-vurderingen her hadde høy verdi for opplevelse av relevans. Denne vurderingsformen ble også en vurdering for og som læring (Smith, 2009; Torrance, 2007). Samtidig peker funnene ifølge deltakerne, på viktigheten av koherens mellom fagene og oppgavene når hverandre-vurdering gis umiddelbart: «(...) hjelper dem til å gjøre det bedre på neste arbeidskrav (...)». Studentene fremhevet mer verdien av virkelighetsnære praktisk-teoretiske yrkesoppgaver og koherens i hverandre-vurderingen, enn selve vurderingens verdi for opplevelse av relevans. Det indikerer at profesjonsretting av vurderingsformer hvor yrkesutøvelsens kompetansebehov gjenspeiles, er sentralt for å fremme relevans (Baartman et al., 2014).

\section{Didaktiske prinsipper for relevant profesjonsutdanning: Konklusjon}

Hvordan kan profesjonsretting og studentaktivitet realiseres? Resultatene samlet viser at profesjonsretting gjennom helhetlig didaktisk relasjonstenkning oppleves nyttig og relevant. I tillegg viste interaksjonen i aksjonsforskningen, med vekt på dialog og kritisk refleksjon å være meget nyttig for deltakernes læring og utviklingsprosesser (Schwencke, 2006).

Utviklingsforsøkene viste at FC kan bidra til å imøtekomme relevansproblematikken, gitt visse didaktiske prinsipper. Selv om deltakerne opplevde nytte av profesjonsretting ved UHped, opplevde mange utfordringer med profesjonsretting i profesjonsutdanningene. Noen deltakere var også lite opptatt av profesjonsretting i starten av UHped-kurset, som kan 
forklares med liten og til dels manglende tradisjon for profesjonsretting og strukturelle rammer i utdanningssystemet.

Den indre sammenhengen i resultatene er sentrale didaktiske prinsipper for profesjonsretting som er i relasjon hverandre gjennom den helhetlige profesjonsdidaktiske relasjonstenkningen. Kjernen i prinsippene er analyse av yrkesoppgaver som utgangspunkt for læreplananalyse og praktisk-teoretisk profesjonsdidaktisk planlegging av innhold, arbeidsmåter og vurdering. Det innebærer koherens knyttet til helhetlig yrkeskompetanse. Forpliktende forberedelser og studentaktiv læring gjennom refleksjon i og over praksis, er også viktig. Resultatene peker også delvis mot hindringer som akademisk kunnskapssyn, tradisjon og kultur. Til dels mangel på didaktisk kompetanse for profesjonsretting i utdanningene synes også å være en utfordring.

Selv om de fleste deltakerne ved UHped hadde positive erfaringer med profesjonsretting, kan det likevel i stor grad bli opp til den enkelte profesjonsutdanner om de profesjonsretter utdanningsinnholdet, arbeidsmåtene og vurderingsformen. Implikasjoner som utpekte seg er i tråd med Meld.St. 16 (2016-2017), hvor jeg vil anbefale videre utvikling av didaktisk lærerkompetanse gjennom didaktisk aksjonsforskning og utviklingsprosjekter.

\section{Litteraturliste}

Amble, N. (2012). Mestring og organisering $i$ arbeid med mennesker - Om bra arbeid for grepa damer (Doktorgradsavhandling). Norges teknisk-naturvitenskapelige universitet, Trondheim.

Baartman, L., Gulikers, J. \& Dijkstra, A. (2014). Factors influencing assessment quality in higher vocational education. Assessment \& Evaluation in Higher Education, (38)8, 978-997. doi:10.1080/02602938.2013.771133

Bergmann, J. \& Sams, A. (2011). How the Flipped Classroom Was Born. Hentet 01.12.2016 fra www.thedailyriff. com/articles/how-the-flipped-classroom-is-radicallytransforming-learning-536.php

Billett, S. (2014a). Integrating learning experiences across tertiary education and practice settings: A socio-personal account. Educational Research Review, 12, 1-13. doi:10.1016/j.edurev.2014.01.002

Billett, S. \& Choy, S. (2013). Learning through work: Emerging perspectives and new challenges. Journal of Workplace Learning, 25(4), 264-275. doi:10.1108/13665621311316447 
Bishop, J. L. \& Verleger, M. A. (2013). The flipped classroom: A survey of the research. Paper presentert på ASEE Annual Conference \& Exposition, Atlanta, GA.

Canrinus, E. T., Bergem, O. K., Klette, K. \& Hammerness, K. (2015). Coherent teacher education programmes: Taking a student perspective. Journal of Curriculum Studies. doi:10.1080/00220272.2015.1124145

Dahlback, J., Hansen, K., Haaland, G. \& Sylte, A. L. (2011). Yrkesdidaktisk kunnskapsutvikling og implementering av nye loereplaner (KIP) - Veien til yrkesrelevant opploering fra første dag $i$ Vgl (Rapporter og utredninger 1/2011). Lillestrøm: Høgskolen i Akershus.

Day, J. A, \& Foley, J. D. (2006). Evaluating a web lecture intervention in a human-computer interaction course. IEEE Transactions on education, 49(4), 420-431. doi:10.1109/TE.2006.879792

Dewey, J. (1910). How we think. Boston: D. C. Heath.

Dreyfus, H.L. \& Dreyfus, S.E (1986). Mind over Machine. The Power of Human Intuition and Expertice in the Era of the Computer. New York: Free press.

Eikeland, O. (2006). The validity of action research - validity in action research. I K. Aagaard Nielsen \& L. Svensson (Red.), Action and interactive research: Beyond theory and practice (s. 193-240). Maastricht: Shaker Publishing.

Forskrift om ansettelse og opprykk. (2006). Forskrift om ansettelse og opprykk $i$ undervisnings- og forskerstillinger. Hentet fra https://lovdata.no/forskrift/2006-02-09$\underline{129}$

Forskrift om rammeplan for lektorutdanning. (2013). Forskrift om rammeplan for lektorutdanning for trinn 8-13. Hentet fra https://lovdata.no/forskrift/2013-03-18-288

Gadamer, H. G. (2010). Sannhet og metode: Grunntrekk $i$ en filosofisk hermeneutikk (L. Holm-Hansen, Overs.). Oslo: Bokklubben. (1. utgivelse 1960)

Grimen, H. (2004). Samfunnsvitenskapelige tenkemåter. Oslo. Universitetsforl.

Grimen, H. (2008). Profesjon og kunnskap. I A. Molander \& L. I. Terum (Red.), Profesjonsstudier (s. 71-86). Oslo: Universitetsforl.

Hatlevik, I. K. R. (2014). Meningsfulle sammenhenger (Doktorgradsavhandling). Høgskolen i Oslo og Akershus, Oslo. (HiOA avhandlinger 2014 nr. 4)

Hattie, J. \& Timperley, H. (2007). The power of feedback. Review of Educational Research, 77(1), 81-112. doi:10.3102/003465430298487

Heggen, K. \& Smeby, J. C. (2012). Gir mest mulig samanheng også den beste profesjonsutdanninga? Norsk pedagogisk tidsskrift, 96(1), 4-14. 
Hiim, H. (2010). Pedagogisk aksjonsforskning: Tilncerminger, eksempler og kunnskapsfilosofisk grunnlag. Oslo: Gyldendal akademisk.

Hiim, H. (2013). Praksisbasert yrkesutdanning: Hvordan utvikle relevant yrkesutdanning for elever og arbeidsliv? Oslo: Gyldendal akademisk.

Hiim, H. (2014). Yrkesretting av fellesfag. I M. B. Postholm \& T. Tiller (Red.), Profesjonsrettet pedagogikk 8-13 (s. 178-200). Oslo: Cappelens Damm akademisk.

Hiim, H. (2015). Kvalitet i yrkesutdanningen: Resultater fra et aksjonsforskningsprosjekt om yrkesforankring av innholdet i yrkesutdanningen. Norsk pedagogisk tidsskrift, 99(2), 136-148.

Hiim, H. \& Hippe, E. (2001). A utdanne profesjonelle yrkesutøvere. Oslo: Gyldendal akademisk.

Kolb, D. A. (2012). Erfaringslæring: Processen og det strukturelle grundlag. I K. Illeris (Red.), 49 tekster om loering (s. 283-298). Fredriksberg: Samfundslitteratur. (1. utgivelse 1984)

Kvale, S. \& Brinkmann, S. (2009). Det kvalitative forskningsintervju (2. utg., T. M. Anderssen \& J. Rygge, Overs.). Oslo: Gyldendal akademisk.

Lage, M. J., Platt, G. J. \& Treglia, M. (2000). Inverting the classroom: A gateway to creating an inclusive learning environment. The Journal of Economic Education, 31(1), 3043.

McNiff, J. \& Whitehead, J. (2006). All you need to know about Action Research. London: Sage Publications.

Meld. St. 16 (2016-2017). Kultur for kvalitet $i$ høyere utdanning. Oslo:

Kunnskapsdepartementet. Hentet 04.06.2017:

https://www.regjeringen.no/contentassets/aee30e4b7d3241d5bd89db69fe38f7ba/no/pd fs/stm201620170016000dddpdfs.pdf

Meld. St. 13 (2011-2012). Utdanning for velferd: Samspill i praksis. Oslo: Kunnskapsdepartementet.

Michelsen, S. \& Aamodt, P. O. (2007). Evaluering av Kvalitetsreformen: Sluttrapport. Oslo: Norges forskningsråd.

Molander, A. \& Terum, L. (Red.). (2008). Profesjonsstudier. Oslo: Universitetsforl.

Nielsen, K. A. (1996). Arbejdes sociale orientering. København: Forlaget Sociologi.

NOKUT. (2006). Evaluering av allmennloererutdanningen i Norge 2006: Dell:

Hovedrapport. Oslo: Nasjonalt organ for kvalitet i utdanningen.

Reason, P. \& Bradbury, H. (2008). Introduction. I P. Reason \& H. Bradbury (Red.), The 
SAGE handbook of action research: Participative inquiry and practice (s. 1-10). London: Sage Publications.

Schön, D. A. (1983). The reflective practitioner: How professionals think in action. New York: Basic Books.

Schön, D. A. (1995). Knowing-in-action: The new scholarship requires a new epistemology. Change: The Magazine of Higher Education, 27(6), 27-34.

Smeby, J.-C. (2008). Profesjon og utdanning. I A. Molander, A. \& L. I. Terum (Red.), Profesjonsstudier (87-102). Oslo: Universitetsforl.

Smeby, J.-C. \& Mausethagen, S. (2011). Kvalifisering til «velferdsstatens yrker». I Statistisk sentralbyrå, Utdanning 2011 - veien til arbeidslivet (Statistiske analyser nr. 124, s. 149-169). Oslo: SSB.

Smith, K. (2009). Samspillet mellom vurdering og motivasjon. I S. Dobson, A. B. Eggen \& K. Smith (Red.), Vurdering, prinsipper og praksis (s. 23-39). Oslo: Gyldendal akademisk.

Statistisk sentralbyrå. (2014). Gjennomstrømning i høyere utdanning 2012/2013. Hentet 08.12.2016 fra https://www.ssb.no/utdanning/statistikker/hugjen/aar/2014-06-26

St.meld. nr. 7 (2007-2008). Statusrapport for Kvalitetsreformen i høgre utdanning. Oslo: Kunnskapsdepartementet.

St.meld. nr. 11 (2008-2009). Lareren: Rollen og utdanningen. Oslo:

Kunnskapsdepartementet.

Strauss, A. \& Corbin, J. M. (1997). Grounded Theory in Practice. Thousand Oaks, Calif.: Sage Publications.

Sullivan, W. M. \& Benner, P. (2005). Challenges to Professionalism: Work Integrity and the Call to Renew and Strengthen the Social Contract of the Professions. American journal of critical care, 14(1), 78-80, 84 .

Svensson, L. \& Nielsen, K. A. (2006). A framework for the book. I K. A. Nielsen \& L. Svensson (Red.), Action research and interactive research (s. 13-45). Maastricht: Shaker Publishing.

Schwencke, E. (2006). Free Space in Action Research and in Project Oriented Traineeship. I K. A. Nielsen \& L. Svensson (Red.) Action and Interactive Research: Beyond Practice and Theory. Maastricht: Shaker Publishing.

Sylte, A. L. (2014). Vurdering for yrkesrelevant opplæring. Nordic Journal of Vocational Education and Training, 4(1), 1-18. doi:10.3384/njvet.2242-458X.14v4i1a4

Sylte, A. L. (2015). Yrkesretting av teorien og yrkesdifferensiering - En vei for å hindre frafall ved yrkesopplæringen i videregående skole. I O. Eikeland, H. Hiim \& E. 
Schwencke (Red.), Yrkespedagogiske perspektiver (s. 140-167). Oslo: Gyldendal akademisk.

Sylte, A. L. (2016). Profesjonspedagogikk: Profesjonsretting / yrkesretting av pedagogikk og didaktikk (2. utg.). Oslo: Gyldendal akademisk.

Terum, L. I. \& Smeby, J-C. (2014). Akademisering, kvalitet og relevans. I N. Frølich, E. Hovdhaugen \& L. I. Terum (Red.), Kvalitet, kapasitet \& relevans: Utviklingstrekk $i$ norsk høyere utdanning (s. 114-139). Oslo: Cappelen Damm akademisk.

Torrance, H. (2007). Assessment as learning? How the use of explicit learning objectives, assessment criteria and feedback in post-secondary education and training can come to dominate learning. Assessment in Education: Principles, Policy \& Practice, 14(3), 281-294. doi:10.1080/09695940701591867

Young, M. (2004). Conceptualizing vocational knowledge. Some theoretical considerations. I H. Rainbird, A. Fuller \& A. Munro (red.), Workplace learning in context (s. 186-200). London: Routledge.

\footnotetext{
' Prosjektet Profesjonsretting av høyere utdanning var i regi Senter for profesjonsstudier (SPS) og Fakultet for Lærerutdanning og internasjonale studier, institutt for yrkesfaglærerutdanning (YLU) (2012-2014). Jeg var kursmedansvarlig ved Universitets- og høgskolepedagogisk basiskompetanse (UHped) ved HiOA under ledelse av Anton Havnes og tilsvarende Ped.basiskurs for politiutdannere ved Politihøgskolen (PHS) under ledelse av Ragnhild Holm. Kursene inngikk i mitt forskningsprosjekt som jeg ledet. Siden analysen av utviklingsforsøkene ved HiOA og PHS hadde samme fokus, omtales de videre under ett, som UHped. Studien er godkjent av Norsk Samfunnsvitenskapelige Datatjeneste med saksnummer 37494 og ledelsen ved SPS, YLU og PHSs Pedkurs.

ii Her brukes fagplan om læreplan/ programplan/ emneplan i høyere utdanning.
} 